\title{
Risk Factors of Myocardial Infarction in the Northern Region of Bangladesh
}

\author{
S. Yesmin, M. S. Huda, P. K. Biswas, M. I. I. Wahed, T. Naz" \\ Department of Pharmacy, University of Rajshahi, Rajshahi 6205, Bangladesh
}

Received 30 July 2015, accepted in final revised form 5 September 2015

\begin{abstract}
The worldwide rising incidence of cardiovascular diseases and the associated risk factors could be country or area specific. A case control study identifying important risk factors of myocardial infarction (MI) prevailing in the northern region of Bangladesh, was conducted in two major northern region hospitals, Rajshahi and Rangpur Medical College for a period of 6 months. Majority of the cases $(66 \%)$ and controls $(56 \%)$ were in the age range of $41-$ 60 years. The proportion of male, married and urban residents were predominant in both the case and control group. The highest percentage of patients with MI were involved in business comparatively patients without MI. Clinical symptoms like chest pain, epigastric pain, breathlessness, dizziness and fatigue were observed to be somewhat higher in cases compared to controls. The logistic regression analysis showed that smoking habit, smokeless tobacco consumption, sedentary lifestyle and dyslipidemia were found independent predictors of MI in northern district patients with odds ratio (OR) $(95 \%$ confidence interval) being 3.1 (1.2 to 3.7), 2.5 (1.0 to 3.5), 2.0 (1.1 to 3.6) and 2.3 (1.3 to 4.1 ), respectively.
\end{abstract}

Keywords: Myocardial infarction (MI); Risk Factors; Case control study.

C) 2016 JSR Publications. ISSN: 2070-0237 (Print); 2070-0245 (Online). All rights reserved. doi: http://dx.doi.org/10.3329/jsr.v8i1.24375 J. Sci. Res. 8 (1), 81-92 (2016)

\section{Introduction}

Myocardial infarction (MI) is defined as myocardial cell death due to prolonged ischemia. In MI, the coronary arteries that supply blood to heart become completely obstructed. This obstruction is usually caused by the build-up of plaque in the artery walls or a thrombus in the coronary artery that has developed over the years. A decrease in the amount of oxygen in the blood or in the body's organs can also trigger a heart attack. Moreover, current research suggests that MI may also occur as the result of an inflammation of the heart, which is considered to be the easiest way for the formation of a clot $[1,2]$.

In western countries coronary heart disease appeared as an epidemic after World War II. At present MI is the leading underlying cause of death in developed countries. It imposes disability, loss of productivity and a high economic burden as the treatment costs

\footnotetext{
Corresponding author: naz tarannum@yahoo.com
} 
of the disease increase with the disease progression [3-5]. In 2005, approximately 7.6 million deaths were reported worldwide due to coronary heart diseases [6]. The risk of cardiovascular disease (CVD) is rising both in high-income countries and low- and middle-income countries. However the burden is greater in low- and middle-income counties (more than $80 \%$ ) due to larger population sizes and widespread exposure of increasing levels of risk factors (e.g. unhealthy diet, physical inactivity etc.) [7]. Risk factors of CVDs have been identified from different regions. But some of these risk factors cannot be generalized without a global survey and it has been observed that these risk factors are country or area specific [8]. Common risk factors such as smoking, hypertension, raised lipids and diabetes have been claimed as major risk factors of MI [9]. Cigarette smoking is also another risk factor of fatal and non-fatal heart attacks in both men and women [10]. According to the INTERHEART China study, diabetes and psychological factors were the important risk factors of MI [11]. High triglyceride concentrations, low concentrations of high-density-lipoprotein (HDL) cholesterol, increased visceral fat and insulin resistance are more prevalent among South Asians and these factors have been proposed as reasons for the higher risk of ischemic heart disease (IHD) $[12,13]$.

The consequences of globalization and urbanization contributed to the rising burden of CVD in the developing world [14]. About $80 \%$ of deaths and $85 \%$ of disability from CVD occur in developing countries $[15,16]$. In a recent survey, coronary artery diseases (CAD) are the leading death cause in Bangladesh. There is a dramatic increase in CVD from 1986 to 2006 and the age standardized CVD mortality rates increased by 30 -fold among males and 47-fold in females [9]. Thus, each year a significant number of the active work force is lost, imposing a heavy burden on the society. These facts emphasize the importance of identifying risk factors at a country level. In Bangladesh different regions have different environmental condition, soil composition and lifestyle (e.g. dietary habits, salt intake etc.). Therefore, once the country/area specific risk factors are identified, it will facilitate the health officials to focus on their preventive activities and to carry out the preventive programmes effectively and efficiently. Many studies have been conducted on patients with MI, but little published information about risk factors contributing MI in Bangladeshi patients is available. Taking into consideration of these facts the present case control study has been carried out to identify the important risk factors of myocardial infarction prevailing in the northern region of Bangladesh.

\section{Experimental}

\subsection{Study setting}

The present case - control study was conducted in Cardiology department of Rajshahi Medical College Hospital and Rangpur Medical College Hospital over a period 6 months from September 2014 to February 2015. One hundred consecutive cases of the first attack of MI compared to 100 healthy controls were used. Informed written consent was taken from all the enrolled subjects after a full explanation of the purpose of study and liberty to 
drop out. The questionnaires were first prepared in English and then translated into Bengali for easy comprehension. All the patients were interviewed while in hospital, all the information was filled up in a specially designed pretested questionnaire.

\subsection{Selection of cases and controls}

\subsubsection{Cases}

Patients with first episode of MI who presented within $24 \mathrm{~h}$ of the onset of the chest pain admitted to clinical care unit were recruited. The diagnosis of MI was formally established as recommended by World Health Organization (WHO) with patients fulfilling at least two of the following criteria:

(i) A suggestive history of chest pain.

(ii) Typical changes on the ECG having ST segment elevation of $>1 \mathrm{~mm}$ in at least 2 contiguous chest leads or new onset left bundle branch block.

(iii) Elevation of enzyme creatine kinase at least two times the upper normal level with $10 \%$ CK-MB fraction.

\subsubsection{Controls}

Controls were selected during the same period of time or within seven days, among the patients who presented to the outpatient department of the same hospital with other ailments, unrelated to cardiovascular diseases. For the selection of proper control person's prior history regarding CAD inquiry was made and it was assured that the control had never been admitted to hospital or taken treatment for MI.

\subsubsection{Exclusion criteria}

Any person having evidence of disease which may adversely affect the outcome was not included in case or control group. They were

- $\quad$ Patients who presented $>24 \mathrm{~h}$ after the onset of chest pain

- Patients with history of previous MI

- Patients with liver disease

- Patients with renal disease

- Patients with joint pain

- Patients with hypothyroid/hyperthyroid disease

- Patients with CVD

- Patients with anaemia

- Chronic obstructive lung disease 


\subsection{Assessment of Outcomes}

Once the patient's general conditions were stable, details such as personal variables, information regarding known history of diabetes mellitus (DM) and hypertension, smoking habit, family history of IHD, and early death were collected using an interviewer administered questionnaire. We defined income from salary, business, income of all other members of family and land was considered for calculation of total income. Patients were labeled as having sedentary lifestyle that were not doing any manual work, field duty or undertaking regular walk or exercise. The height and weight of patients was noted and Body Mass Index (BMI) in $\mathrm{kg} / \mathrm{m}^{2}$ was calculated. Patients were labeled as having normal BMI in range of $18.5-24.5 \mathrm{~kg} / \mathrm{m}^{2}$, over weight with BMI in the range of $25-29.9 \mathrm{~kg} / \mathrm{m}^{2}$ and obese with BMI greater than $30 \mathrm{~kg} / \mathrm{m}^{2}$. Those with BMI less than $18.5 \mathrm{~kg} / \mathrm{m}^{2}$ were underweight. Patients with persistent elevation of blood pressure $(\geq 140 / 90 \mathrm{~mm} \mathrm{Hg})$ or who were on anti-hypertensive drugs were classified as hypertensives [17]. Diabetes was defined using the American Diabetes Association criteria of fasting plasma glucose $>125$ $\mathrm{mg} / \mathrm{dL}[18]$ or patients taking hypoglycemic drugs. According to the criteria of National Cholesterol Education Program, Adult Treatment Panel III Dyslipidemia was defined as hypercholesterolemia, hypertriglyceridemia, high low density lipoprotein (LDL) and low HDL [19].

\subsection{Statistical Analysis}

Data were processed and analyzed using computer software SPSS (Statistical Package for Social Sciences), version 11.5. Student's t-test was used for comparison of the continuous variables. Pearson's chi-square test (both two-sided) was used for comparison of the categorical variables and logistic regression was used to predict the risk factors of MI. A value of $\mathrm{P}<0.05$ was considered as statistically significant.

\section{Results}

The result shows that majority of the cases $(66 \%)$ and controls $(56 \%)$ were in the age range of $41-60$ years with mean age $51.7 \pm 11.0$ and $54.5 \pm 12.9$ years, respectively. The proportion of male, married and urban residents were predominant in the both case and control group ( $75 \%$ vs. $66 \%$; $95 \%$ vs. $95 \%$ and $60 \%$ vs. $55 \%$ respectively). The highest percentage of patients with MI were involved in business comparatively patients without MI. Primary, SSC and HSC level educated were more prevalent in case group, while illiterate, graduate and above level were in control group. The largest number of cases (61\%) and controls (46\%) had monthly income between Taka 10,000 - 20,000. Most of the patients in case and control groups were normal weight. $41 \%$ of cases were overweight and $3 \%$ obese than those of $31 \%$ of controls were over-weight and $50 \%$ obese. All of the variables except occupation were homogeneously distributed between groups as evident by $\mathrm{p}>0.05$ (Table 1 ). 
Table 1. Comparison of demographic and anthropometric characteristics between groups.

\begin{tabular}{|c|c|c|c|}
\hline \multirow{2}{*}{$\begin{array}{l}\text { Demographic \& } \\
\text { anthropometric } \\
\text { characteristics }\end{array}$} & \multicolumn{2}{|l|}{ Group } & \multirow[t]{2}{*}{$\mathrm{p}$ value } \\
\hline & Case $(n=100)$ & Control $(\mathrm{n}=100)$ & \\
\hline \multicolumn{4}{|l|}{ Age (years) } \\
\hline$\leq 40$ & $17(17.0)$ & $14(14.0)$ & \\
\hline $41-60$ & $66(66.0)$ & $56(56.0)$ & \\
\hline$>60$ & $17(17.0)$ & $30(30.0)$ & \\
\hline Mean \pm SD $^{\#}$ & $51.7 \pm 11.0$ & $54.5 \pm 12.9$ & 0.108 \\
\hline \multicolumn{4}{|l|}{ Gender* } \\
\hline Male & $75(75.0)$ & $66(66.0)$ & 0.163 \\
\hline Female & $25(25.0)$ & $34(34.0)$ & \\
\hline \multicolumn{4}{|l|}{ Marital status* } \\
\hline Married & $95(95.0)$ & $96(96.0)$ & 0.500 \\
\hline Unmarried & $5(5.0)$ & $4(4.0)$ & \\
\hline \multicolumn{4}{|l|}{ Residence* } \\
\hline Rural & $40(40.0)$ & $45(45.0)$ & 0.474 \\
\hline Urban & $60(60.0)$ & $55(55.0)$ & \\
\hline \multicolumn{4}{|l|}{ Occupation* } \\
\hline Business & $30(30.0)$ & $16(16.0)$ & \\
\hline Service & $21(21.0)$ & $25(25.0)$ & 0.007 \\
\hline Farmer & $19(19.0)$ & $11(11.0)$ & \\
\hline Housewife & $23(23.0)$ & $27(27.0)$ & \\
\hline Unemployed & $7(7.0)$ & $21(21.0)$ & \\
\hline \multicolumn{4}{|l|}{ Educational status* } \\
\hline Illiterate & $14(14.0)$ & $26(26.0)$ & \\
\hline Primary & $26(26.0)$ & $21(21.0)$ & 0.199 \\
\hline $\mathrm{SSC}$ & $17(17.0)$ & $11(11.0)$ & \\
\hline HSC & $23(23.0)$ & $19(19.0)$ & \\
\hline Graduate \& above & $20(20.0)$ & $23(23.0)$ & \\
\hline \multicolumn{4}{|l|}{ Monthly income (Taka) } \\
\hline$<10000$ & $18(18.0)$ & $21(21.0)$ & \\
\hline $10000-20000$ & $61(61.0)$ & $46(46.0)$ & \\
\hline$\geq 20000$ & $21(21.0)$ & $33(33.0)$ & \\
\hline$\overline{M e a n} \pm \mathrm{SD}^{\#}$ & $13697 \pm 6319$ & $14538 \pm 8213$ & 0.543 \\
\hline \multicolumn{4}{|l|}{ Body Mass Index } \\
\hline$\left(\mathrm{Kg} / \mathrm{m}^{2}\right)$ & 00 & $3(3.0)$ & \\
\hline Underweight (<18.5) & $56(56.0)$ & $61(61.0)$ & \\
\hline Normal (18.5 - 24.5) & $41(41.0)$ & $31(31.0)$ & \\
\hline Over-weight $(25-29.9)$ & $3(3.0)$ & $5(50.0)$ & \\
\hline \multicolumn{4}{|l|}{ Obese $(>30)$} \\
\hline Mean $\pm \mathrm{SD}^{\#}$ & $24.6 \pm 3.0$ & $24.2 \pm 5.1$ & 0.563 \\
\hline
\end{tabular}

Figure in the parentheses denoted corresponding percentage

*Data were analyzed using Chi-square $\left(\chi^{2}\right)$ Test

\# Student $\mathrm{t}$ Test was done to analyze the data and presented as Mean $\pm \mathrm{SD}$.

Clinical symptoms like chest pain, epigastric pain, breathlessness, dizziness and fatigue were observed to be somewhat higher in cases compared to controls $(96 \%$ vs. $91 \%, \mathrm{p}=0.152 ; 60 \%$ vs. $58 \%, \mathrm{p}=0.774 ; 74 \%$ vs. $68 \%, \mathrm{p}=0.350 ; 50 \%$ vs. $49 \%, \mathrm{p}=$ 0.888 and $49 \%$ vs. $44 \%, p=0.478$ respectively). Over half $(54 \%)$ of the cases presented 
with nausea and vomiting than $37 \%$ of controls $(\mathrm{p}=0.016)$ (Table 2$)$. The data of biochemical investigations shows that mean total cholesterol and triglyceride were significantly higher in case group $(197.3 \pm 28.9$ vs. $178.1 \pm 20.7 \mathrm{mg} / \mathrm{dL}, \mathrm{p}=0.021$ and $193.5 \pm 33.7$ vs. $148.6 \pm 31.5 \mathrm{mg} / \mathrm{dL}, \mathrm{p}=0.047$ respectively). Conversely, mean HDL and LDL cholesterol were significantly higher in control group $(51.8 \pm 22.7$ vs. $44.2 \pm 13.5$ $\mathrm{mg} / \mathrm{dL}, \mathrm{p}=0.004$ and $111.3 \pm 38.4$ vs. $103.1 \pm 38.3 \mathrm{mg} / \mathrm{dL}, \mathrm{p}<0.001$ respectively). The mean fasting blood glucose was higher in case group than that in control group, although the difference did not reach the level of significance $(p=0.616)$ (Table 3$)$.

Table 2. Comparison of presenting symptoms between groups.

\begin{tabular}{llll}
\hline Presenting symptoms & Group & \\
\cline { 2 - 3 } & Case $(\mathrm{n}=100)$ & Control $(\mathrm{n}=100)$ & $\begin{array}{l}\mathrm{p} \\
\text { value }\end{array}$ \\
\hline Chest pain & $96(96.0)$ & $91(91.0)$ & 0.152 \\
Nausea \& vomiting & $54(54.0)$ & $37(37.0)$ & 0.016 \\
Epigastric pain & $60(60.0)$ & $58(58.0)$ & 0.774 \\
Breathlessness & $74(74.0)$ & $68(68.0)$ & 0.350 \\
Dizziness & $50(50.0)$ & $49(49.0)$ & 0.888 \\
Fatigue & $49(49.0)$ & $44(44.0)$ & 0.478 \\
\hline
\end{tabular}

Figure in the parentheses denoted corresponding percentage

*Data were analyzed using Chi-square $\left(\chi^{2}\right)$ Test

Table 3. Comparison of different biochemical parameters between groups.

\begin{tabular}{|c|c|c|c|}
\hline \multirow[b]{2}{*}{ Biochemical parameters } & \multicolumn{2}{|l|}{ Group } & \multirow[b]{2}{*}{$p$ value } \\
\hline & Case $(\mathrm{n}=100)$ & Control $(n=100)$ & \\
\hline $\begin{array}{lll}\begin{array}{l}\text { Fasting } \\
(\mathrm{mg} / \mathrm{dL})\end{array} & \text { blood } & \text { glucose } \\
\end{array}$ & $159.8 \pm 60.2$ & $99.8 \pm 21.6$ & 0.616 \\
\hline Total cholesterol $(\mathrm{mg} / \mathrm{dL})$ & $197.3 \pm 28.9$ & $178.1 \pm 20.7$ & 0.021 \\
\hline Triglyceride $(\mathrm{mg} / \mathrm{dL})$ & $193.5 \pm 33.7$ & $148.6 \pm 31.5$ & 0.047 \\
\hline $\mathrm{HDL}(\mathrm{mg} / \mathrm{dL})$ & $44.2 \pm 13.5$ & $51.8 \pm 22.7$ & 0.004 \\
\hline $\mathrm{LDL}(\mathrm{mg} / \mathrm{dL})$ & $103.1 \pm 38.3$ & $111.3 \pm 38.4$ & $<0.001$ \\
\hline
\end{tabular}

\# Student $\mathrm{t}$ Test was done to analyze the data and presented as Mean $\pm \mathrm{SD}$.

The suspected risk factors like history of hypertension, diabetes, sedentary lifestyle, smoking habit, smokeless tobacco consumption, family H/O IHD, family H/O diabetes, family $\mathrm{H} / \mathrm{O}$ hypertension, dyslipidemia and heavy fat diet were observed significantly higher in cases than that in controls $(77 \%$ vs. $59 \%, \mathrm{p}=0.006 ; 51 \%$ vs. $37 \%, \mathrm{p}=0.046$; $46 \%$ vs. $30 \%, p=0.020 ; 63 \%$ vs. $45 \%, p=0.011 ; 39 \%$ vs. $25 \%, p=0.034 ; 28 \%$ vs. $16 \%$, $\mathrm{p}=0.041 ; 53 \%$ vs. $36 \%, \mathrm{p}=0.016 ; 69 \%$ vs. $63 \%, \mathrm{p}=0.020 ; 62 \%$ vs. $41 \%, \mathrm{p}=0.003$ and $48 \%$ vs. $43 \%, \mathrm{p}=0.031$ respectively). However, other risk factors smoking status, cigarettes consume per day, duration of smoking, duration of smokeless tobacco consumption, family $\mathrm{H} / \mathrm{O}$ early death, taking salt with meal, vegetarianism, habit of exercise and parental consanguinity were almost identically distributed between groups ( $p$ $>0.05$ ) (Table 4). The binary logistic regression analysis of Odds Ratio for characteristics of the patients likely to cause MI are shown in Table 5. The variables revealed to be 
significantly associated with MI in univariate analysis were entered into the model directly. Of the 10 variables, smoking habit, smokeless tobacco consumption, sedentary lifestyle and dyslipidemia were found to be the independent predictors of MI with ORs being 3.1, 2.5, 2.0 and 2.3, respectively. These mean that patients with smoking habit, smokeless tobacco consumption, sedentary lifestyle and dyslipidemia were 3.1, 2.5, 2.0 and 2.3 times higher in risk of developing MI than patients who did not have such history.

Table 4. Univariate analysis of suspected risk factors of MI.

\begin{tabular}{|c|c|c|c|}
\hline \multirow{2}{*}{ Suspected risk factors } & \multicolumn{2}{|l|}{ Group } & \multirow{2}{*}{$\mathrm{p}$ value } \\
\hline & Case $(n=100)$ & Control $(n=100)$ & \\
\hline History of hypertension & $77(77.0)$ & $59(59.0)$ & 0.006 \\
\hline History of diabetes & $51(51.0)$ & $37(37.0)$ & 0.046 \\
\hline Sedentary lifestyle & $46(46.0)$ & $30(30.0)$ & 0.020 \\
\hline Smoking habit & $63(63.0)$ & $45(45.0)$ & 0.011 \\
\hline Current & $38(60.3)$ & $21(46.7)$ & 0.160 \\
\hline Past & $25(39.7)$ & $24(53.3)$ & \\
\hline \multicolumn{4}{|l|}{ Cigarettes/day } \\
\hline$<10$ & $17(27.0)$ & $18(40.0)$ & 0.154 \\
\hline$\geq 10$ & $46(73.0)$ & $27(60.0)$ & \\
\hline \multicolumn{4}{|l|}{ Duration of smoking } \\
\hline$<10$ years & $12(19.0)$ & $9(20.0)$ & 0.902 \\
\hline$\geq 10$ years & $51(81.0)$ & $36(80.0)$ & \\
\hline $\begin{array}{ll}\text { Smokeless } & \text { tobacco } \\
\text { consumption } & \end{array}$ & $39(39.0)$ & $25(25.0)$ & 0.034 \\
\hline Current & $26(66.7)$ & $8(32.0)$ & 0.107 \\
\hline Past & $13(33.3)$ & $17(68.0)$ & \\
\hline \multicolumn{4}{|l|}{ tobacco consumption } \\
\hline$<10$ years & $9(23.1)$ & $7(28.0)$ & 0.657 \\
\hline$\geq 10$ years & $30(76.9)$ & $18(72.0)$ & \\
\hline Family H/O IHD & $28(28.0)$ & $16(16.0)$ & 0.041 \\
\hline Family H/O DM & $53(53.0)$ & $36(36.0)$ & 0.016 \\
\hline Family $\mathrm{H} / \mathrm{O}$ hypertension & $69(69.0)$ & $53(53.0)$ & 0.020 \\
\hline Family $\mathrm{H} / \mathrm{O}$ early death & $26(26.0)$ & $18(18.0)$ & 0.258 \\
\hline Dyslipidemia & $62(62.0)$ & $41(41.0)$ & 0.003 \\
\hline Heavy fat diet & $48(48.0)$ & $33(33.0)$ & 0.031 \\
\hline Taking salt with meal & $64(64.6)$ & $53(53.0)$ & 0.095 \\
\hline Vegetarianism & $67(67.0)$ & $70(70.0)$ & 0.648 \\
\hline Habit of exercise & $14(14.0)$ & $17(17.0)$ & 0.558 \\
\hline Parental consanguinity & $31(31.0)$ & $26(26.0)$ & 0.434 \\
\hline
\end{tabular}

Figure in the parentheses denoted corresponding percentage

*Data were analyzed using Chi-square $\left(\chi^{2}\right)$ Test

Table 5. Influencing factors of MI.

\begin{tabular}{llll}
\hline Variables of interest & $\begin{array}{l}\text { Univariate analysis } \\
\text { (p value) }\end{array}$ & $\begin{array}{l}\text { Multivariate analysis } \\
\text { Odds Ratio (95\% CI of OR) }\end{array}$ & p value \\
\hline History of hypertension & 0.006 & $2.3(1.3-4.2)$ & 0.264 \\
History of diabetes & 0.046 & $1.8(1.0-3.1)$ & 0.841 \\
Smoking habit & 0.011 & $3.1(1.2-3.7)$ & 0.001
\end{tabular}




\begin{tabular}{llll}
\hline Variables of interest & $\begin{array}{l}\text { Univariate analysis } \\
(\mathrm{p} \text { value })\end{array}$ & $\begin{array}{l}\text { Multivariate analysis } \\
\text { Odds Ratio }(95 \% \text { CI of OR) }\end{array}$ & p value \\
\hline $\begin{array}{l}\text { Smokeless tobacco } \\
\text { consumption }\end{array}$ & 0.034 & $2.5(1.0-3.5)$ & 0.007 \\
$\begin{array}{l}\text { Family H/O IHD } \\
\text { Sedentary lifestyle }\end{array}$ & 0.041 & $2.0(1.0-4.1)$ & 0.336 \\
Family H/O diabetes & 0.020 & $2.0(1.1-3.6)$ & 0.002 \\
mellitus & 0.016 & $2.0(1.1-3.5)$ & 0.193 \\
Family H/O hypertension & 0.020 & $1.9(1.1-3.5)$ & 0.847 \\
Dyslipidemia & 0.003 & $2.3(1.3-4.1)$ & 0.032 \\
Heavy fat diet & 0.031 & $1.8(1.1-3.3)$ & 0.126 \\
\hline
\end{tabular}

CI- confidence interval; OR- odds ratio.

\section{Discussion}

Over past three decades, the incidence of heart attacks and strokes among South Asians has risen sharply and Bangladesh has the highest rate of CVD in comparison to all South Asian countries. The identification of classic risk factors e.g. blood fats, blood pressure, diabetes and smoking has resulted to decrease in CAD related deaths in high income countries. Although the same risk factors also apply to South Asians, but still the incidence of CAD is increasing at a greater rate in South Asia than in any other regions globally. Therefore it can be assumed that they may be affected by additional or unrecognized factors $[9,20]$. The present study has focused on risk factors of MI in northern region of Bangladesh.

In the present study majority of the cases $(66 \%)$ were in the age range of $41-60$ years with mean age $51.7 \pm 11.0$ years as compared to $52 \pm 10.8$ years in a study reported by Jafary et al. [21] and $58 \pm 11$ years by Samad et al. [22] in Pakistan and $62 \pm 5$ in COURAGE trial [23] conducted in USA. Regarding the gender study group, the higher percentages of the study samples were males $(75 \%)$. This result comes along with the studies by several researchers [24-25], according to them, the male was the dominant gender. In addition, the gender differences, in the broad scope of health and illness, have been the subject of extensive investigation and are also currently gaining more attention in nursing. Women and men emphasize different aspects of their lives when evaluating their level of quality of life and life satisfaction leading to the fact that the MI is more common in men than in women. Most of our patients with MI were businessman and educated. This revealed that businessman were more affected by MI, might be due to change into affluent lifestyle. This finding was co-related with the studies of several researchers [2628] focused on the relation between IHD and economic development. These studies also showed that major portion of MI patients was found educated would be due to awareness of such people which was coincide with our finding.

A case-control study reported by Lanas and coauthors [29] involving 1237 cases of first acute MI from six Latin American countries of Argentina, Brazil, Colombia, Chile, Guatemala and Mexico. They identified risk factors for acute MI in Latin America and provided important information about the population-attributable risk (PAR). According 
to them, the 9 risk factors for CHD are - abnormal lipid levels, smoking, hypertension, diabetes, abdominal obesity, psychosocial stress, regular physical activity, consumption of fruits, vegetables and alcohol. These risk factors globally account for $90 \%$ or more of the PAR for both men and women [30]. Findings of current study showed that all risk factorshistory of hypertension, diabetes, sedentary lifestyle, smoking, smokeless tobacco consumption, family history of IHD, family history of DM, family history of hypertension, dyslipidemia and heavy fat diet (except vegetarianism and habit of exercise) were significantly more in cases against healthy control subjects. Though vegetarianism being common among people in the northern region of Bangladesh, most of them consume high carbohydrate, high salt and low fiber diet such as green leafy vegetables, which contribute to increase in triglyceride, blood pressure and plasma sugar and also have higher risk for MI [31]. The daily moderate physical activity of brisk walking for 45 min was associated with 50\% reduction in risk for MI [32], which was not commonly practiced in our study subjects. Regular exercise is a major way to reduce the risk of having a further MI. Therefore, physicians should encourage the patients to incorporate physical activity into their lifestyle.

The results of the current research showed that $62 \%$ of cases experienced dyslipidemia and strongly associated with MI with odds ratio 2.3. In a similar study in Iran, T. Kazemi et al. [33] showed $45.7 \%$ of cases had dyslipidemia and found positive association with MI with odds ratio 2.8. In our dataset mean cholesterol and triglyceride were significantly higher in cases. Conversely, HDL and LDL cholesterol were significantly higher in controls. Other previous lipid profile study conducted in MI patients also reported higher TC, TG, LDL-C and lower HDL-C levels in patients than controls [34]. These results are also consistent with the findings published by Ramachandran and associates [35], revealed that lipid abnormalities are widely accepted risk factor for MI and contributed significantly to the risk of $\mathrm{MI}(\mathrm{OR}=2.98,95 \%$ confidence interval $=2.13-4.97)$. Therefore, patients with MI should check the level of lipids in the blood so that they can reduce the second or third attack of heart disease.

Sedentary lifestyle has been shown to be important in the genesis of caloric imbalance, resulting obesity and all consequences of obesity. There was strongest association of MI seen with lack of physical activity. It was observed in $46 \%$ of our patients $(\mathrm{OR}=2.0)$. These findings are close to a study by Gikas et al. [36], while studying prevalence of risk factors of MI in North Italian adults. Coluccielo et al. [37] found 39.6\% prevalence of low physical activity, mainly among males and with an increasing trend with age. The findings are most comparable with the study by Jafary et al. [21]. They stated that $64.3 \%$ prevalence of sedentary lifestyle among patients with CAD from rural areas of Peshawar. The animal models have also now demonstrated beyond any doubt that physical exercise training performance before acute MI effectively reduces infarct size and LV dilation and improves LV function as late as four weeks after infarction [38].

There is incontrovertible evidence that tobacco, in any form (smoked or chewed) is a major risk factor of MI is associated with endothelial dysfunction and can precipitate coronary spasm [39]. In this study, significant number of case and control subjects had 
smoked or were current smokers. All forms of tobacco produce free radicals that deplete antioxidants and cause oxidative damage to DNA, proteins and lipids [40]. In present study a strong statistical association of smoking and MI was found with odds ratio 3.1 ( $\mathrm{p}$ $=0.001)$. Almost similar findings was observed by Ram and Trivedi [41] which illustrated that odds ratio of smoking is 2.96. While smoking plays a major role in heart attack, therefore we have to find healthy smoking alternatives. We should also encourage cigarettes cessation programs.

\section{Limitations}

Our study has certain limitations. The age of the patients were taken from their statement at the time of interview, not from the birth registration card, which might influence the results. We measured glucose and lipid levels once only at the time of admission and previous medical history has not been checked. Many risk factors were considered on the basis of self-reported history of the patients. So there may be recall bias. The present study has been performed on a relatively small sample, a large-scale study need to be conducted to make the findings more reliable.

\section{Conclusion}

MI is associated with several common but mostly preventable risk factors. Significant predictors of MI were smoking habit, smokeless tobacco consumption, sedentary lifestyle and dyslipidemia. All these features can be prevented in terms of control variables. From the present study, we recommend a nationwide initiative to quit smoking, to have more physical activities and we are also proposing screening programs for earlier detection of blood pressure, high blood glucose, dyslipidemia. Large-scale nationwide survey and clinical research should be conducted to determine the different aspects of CADs in Bangladesh. The suggested initiative would help to formulate national policy to combat the deadly epidemic more efficiently in future.

\section{Acknowledgment}

We appreciate all who helped us to conduct the present study. In addition, we are very much grateful to A.B.S. Shah, Statistician of Research and Statistics for his collaboration with this study.

\section{References}

1. E. Antman, J. Bassand, W. Klein, M. Ohman, J. L. L. Sendon, L. Ryden, M. Simoons, and M. Tendera, J. Am. Coll. Cardiol. 36(3), 959 (2000). http://dx.doi.org/10.1016/S07351097(00)00804-4

2. C. Marvaki, G. Argyriou, G. Karkouli, P. Kossivas, A. Marvaki, N. Pilatis, M. Polikandrioti, and Y. Dimoula, Health Science J. 3, 1 (2007).

3. U. Keil, Gesundheitswesen 67(1), 38 (2005). http://dx.doi.org/10.1055/s-2005-858240 
4. K. K. R. Reddy, A. P. Rao, and T. P. K. Reddy, Asia Pacific J. Clin. Nutr. 11(2), 98 (2002). http://dx.doi.org/10.1046/j.1440-6047.2002.00267.x

5. K. Jamrozik, A. Dobson, M. Hobss, P. McElduff, I. Ring, K. D'Este, and M. Crome Australian Inst. Health Welfare 17, 94 (2001). http://www.aihw.gov.au/publications/index.cfm/title/6807

6. WHO, Prevention of Cardiovascular Disease: Guideline for Assessment and Management of Total Cardiovascular Risk (World Health Organization, Geneva, 2007).

7. S. Yusuf, S. Hawken, S. Ounpuu, T. Dans, A. Avezum, F. Lanas, M. McQueen, A. Budaj, P. Pais, J. Varigos, and L. Lisheng, Lancet 364, 937 (2004). http://dx.doi.org/10.1016/S0140$\underline{\text { 6736(04)17018-9 }}$

8. Y. Sobrepeso, S. C. Obesidad, and J. Smith, Circulation 115, 1061 (2007).

9. A. K. M. M. Islam and A. A. S. Majumder. Ind. Heart J. 65, 424 (2013). http://dx.doi.org/10.1016/j.ihj.2013.06.004

10. J. A. Farmer and A. M. Gotto, Heart disease: A Textbook of Cardiovascular Medicine, (WB Saunders, Philadelphia, 1992).

11. K. K. Teo, L. Liu, C. K. Chow, X. Wang, S. Islam, L. Jiang, J. E. Sanderson, S. Rangarajan, and S. Yusuf. Heart 95, 1857 (2009). http://dx.doi.org/10.1136/hrt.2008.155796

12. D. Kritchevsky, A. W. Moyer, W. C. Tesar, and R. F. McCandless. Am. J. Physiol. 185, 279 (1956).

13. Y. Ali, M. S. Islam, A. H. M. K. Alam, M. A. A. Rahman, A. Mamun, M. K. Hossain, A. K. M. M. Hossain, M. S. Parvin, and M. Rashid. J. Sci. Res. 5(2), 325 (2013). http://dx.doi.org/10.3329/jsr.v5i2.12203

14. K. S. Reddy and S. Yusuf, Circulation 97, 596 (1998). http://dx.doi.org/10.1161/01.CIR.97.6.596

15. WHO, The World Health Report 2002: Reducing Risks, Promoting Healthy Life (World Health Organization, Geneva 2002).

16. K. S. Reddy, N. Eng. J. Med. 350, 2438 (2004). http://dx.doi.org/10.1056/NEJMp048024

17. A. V. Chobanian, G. L. Bakris, H. R. Black, W. C. Cushman, L. A. Green, J. L. I. Jr, D. W. Jones, and B. J. Materson, Hypertension 42, 1206 (2003). http://dx.doi.org/10.1161/01.HYP.0000107251.49515.c2

18. American Diabetes Association, Diabetes Care 29, 43 (2006).

19. Executive Summary of the Third Report of the National Cholesterol Education Program (NCEP) Expert Panel on Detection Evaluation and Treatment of High Blood Cholesterol in Adults. JAMA 285, 2486 (2001). http://dx.doi.org/10.1001/jama.285.19.2486

20. Department of Public Health and Primary Care, University of Cambridge. High-risk Hearts: A South Asian Epidemic. http://www.cam.ac.uk/research/news/high-risk-hearts-a-south-asianepidemic

21. M. H. Jafary, A. Samad, M. Ishaq, and S. A. Jawaid, Pak. J. Med. Sci. 23(4), 485 (2007).

22. Z. Samad, A. Rashid, M. A. Khan, S. Mithani, and M. H. Khan, J. Pak. Med. Assoc. 52(1), 45 (2002).

23. W. E. Boden, and R. A. O'rouke, Am. J. Cardiol. 99 (2), 208 (2007). http://dx.doi.org/10.1016/j.amjcard.2006.07.082

24. A. W. Faisal, M. Ayub, T. Waseem, R. S. Khan and S. S. Hasnain, and J. Ayub, Med. Coll. Abbottabad 23(3), 10 (2011). http://www.ayubmed.edu.pk/JAMC/23-3/Faisal.pdf

25. F. Saleem, M. A. Hassali, A. A. Shafie, A. G. Awad, and S. Bashir. Tropical J. Pharm. Res. 10, 125 (2011).

26. A. Rosengren, A. Dotevall, H. Eriksson, and L. Wilhelmsen, Eur. Heart J. 22, 136 (2001). http://dx.doi.org/10.1053/euhj.2000.2179

27. J. R. Buyamba-Kabangu, R. Fagard, J. Staessen, P. Lijnen, and A. Amery, J. Hypertension 5, 371 (1987). http://dx.doi.org/10.1097/00004872-198706000-00018

28. P. M. McKeigue, G. J. Miller, and M. G. Marmot, J. Clin. Epidemiol. 42, 579 (1989). http://dx.doi.org/10.1016/0895-4356(89)90002-4

29. F. Lanas, A. Avezum, L. E. Bautista, R. Diaz, M. Luna, S. Islam, and S. Yusuf, Circulation 115, 1067 (2007). http://dx.doi.org/10.1161/CIRCULATIONAHA.106.633552 
30. C. Sidney, and M. J. Smith, Circulation 115, 1061 (2007). http://dx.doi.org/10.1161/CIRCULATIONAHA.106.683623

31. K. J. Joshipura, F. B. Hu, J. E. Manson, M. J. Stampfer, E. B. Rimm, F. E. Speizer, G. Colditz, and A. Ascherio. Ann. Intern. Med. 134, 1106 (2001). http://dx.doi.org/10.7326/0003-4819134-12-200106190-00010

32. T. Rastogi, M. Vaz, D. Spiegelman, K. S. Reddy, A. V. Bharathi, M. J. Stampfer, W. C. Willett, and A. Ascherio. Int. J. Epidemiol. 33, 759 (2004). http://dx.doi.org/10.1093/ije/dyh042

33. T. Kazemi, G. R. Sharifzadeh, A. Zarban, A. Fesharakinia, M. R. Rezvani, and S. A. Moezy, JRHS 11(2), 77 (2011).

34. N. Patil, V. Chavan, and N. D. Karnik. Ind. J. Clin. Biochem. 22, 45 (2007). http://dx.doi.org/10.1007/BF02912880

35. M. Ramachandran, A. Dipti, R. Chinnaswamy, and T. Ponniah, Diabetology Metabolic Syndrome 2, 32 (2010). http://dx.doi.org/10.1186/1758-5996-2-32

36. A. Gikas, A. Sotiropoulos, D. Panqiotakos, and S. Pappas, Cent. Eur. J. Public Health 12(4), 207 (2004).

37. M. Colucciello, M. T. Tenconi, C. Rabagliati, M. Piazza, M. Orlandi, and C. Cornalba, Annali di igiene: medicina preventiva e di comunita 18(1), 23 (2006).

38. F. Sarit, S. Mickey, Y. Daniel, S. F. Micha, E. Michael, and K. I. Gania. J. Am. Coll. Cardiol. 45, 931 (2005). http://dx.doi.org/10.1016/j.jacc.2004.11.052

39. L. Choudhury and J. D. Marsh, Am. J. Med. 107, 254 (1999). http://dx.doi.org/10.1016/S00029343(99)00218-1

40. M. Dietrich, G. Block, E. P. Norkus, M. Hudes, M. G. Traber, C. E. Cross, and L. Packer, Am. J. Clin. Nutr. 77, 160 (2003).

41. R. Ram and A. Trivedi, Nat. J. Commun. Med. 3(2), 264 (2012). 